\title{
Pendidikan di Era Disrupsi Teknologi atau Perkembangan Teknologi
}

\author{
Oleh
}

\section{Bayu Rikno Pamungkas}

\section{Pendahuluan}

Revolusi industri atau perkembangan teknologi merupakan suatu ilmu yang perkembangannya sangat cepat terjadi yang disebutkan disrupsi teknologi. Perkembangan yang terjadi sangatlah berperan aktif dan memberikan pengaruh dalam segala bidang kehidupan manusia, baik pengaruh positif maupun negative. Seperti salah satunya adalah dalam bidang pendidikan yang mempengaruhi proses pendidikan yang sedang berlangsug. Sehingga, tidak jarang jika banyak para pengajar mengalami kesulitan dalam proses pembelajarannya dikarenakan perkembangan teknologi yang begitu cepat. Sehingga, membuat para guru mengalami kesulitan untuk mengikuti perkembangan teknologi yang terjadi, dan tidak hanya para pengajar saja, melainkan para murid juga mengalami kesulitan yang sama. Seperti yang tertulis dalam Kompas.com, bahwa:

\begin{abstract}
KOMPAS.com - Era disrupsi teknologi yang semakin maju sekarang ini memengaruhi berbagai bidang kehidupan, termasuk dunia pendidikan. Semua pihak yang terlibat, termasuk guru dan murid, diharapkan mampu mengikuti perkembangan zaman. Mereka dihadapkan pada masa yang membutuhkan pemikiran tingkat tinggi, analitis, di luar dari rutinitas, dan tidak manual yang hanya mengikuti kebiasaan yang ada selama ini. Menurut Kepala Badan Penelitian dan Pengembangan Kementerian Pendidikan dan Kebudayaan ( Kemendikbud) Totok Suprayitno, ada tiga tantangan yang harus dihadapi oleh para pelaku pendidikan saat ini. ${ }^{1}$
\end{abstract}

Melalui berita diatas maka dapat dipahami bahwa, pendidikan zaman sekarang sangatlah dipengaruhi oleh perkembangan teknologi atau disrupsi teknologi. Sehingga, mau tidak mau para pengajar dan murid harus menyesuaikan setiap pembelajarannya dengan perkembangan teknologi yang terjadi, meskipun terdapat berbagai tantangan dalam bidang pendidikan yang disebabkan oleh perkembangan teknologi para pengajar maupun murid harus memiliki sikap yang positif terhadapnya sehingga tantangan tersebut dapat diatasi dengan benar.

Prof. M. Surya mendefinisikan pembelajaran atau pendidikan adalah “.... suatu proses yang dilakukan oleh individu untuk memperoleh suatu perubahan perilaku yang baru secara keseluruhan, sebagai hasil dari pengalaman individu itu sendiri dalam interaksi dengan lingkungannya". ${ }^{2}$ Setuju dengan Surya bahwa, pendidikan memiliki tujuan agar seseorang mengalami perubahan. Sehingga, penulis berpendapat, jika pendidikan zaman sekarang mengalami tantangan akibat disrupsi teknologi, maka

\footnotetext{
${ }^{1}$ Kompas.com, https://edukasi.kompas.com/read/2019/09/03/15390441/3-tantanganpendidikan-era-disrupsi-teknologi-apa-saja?page=all. (Di akses 19 September 2019)
}

${ }^{2}$ Moh Surya. Psikologi Pembelajaran dan pengajaran. (Bandung: Pustaka Bani Quraisy), 7 
tujuan tersebut tidak akan tercapai. Sehingga, bagi para pengajar maupun murid harus memahami tantangan-tantangan yang mereka hadapi di era disrupsi teknologi, sehingga mereka akan mencapai tujuan yang diinginkannya, yaitu mengalami suatu perubahan.

Untuk memahami tantangan-tantangan yang terjadi di era disrupsi teknologi ini. Penulis akan mengkaji dan mendeskripsikan lebih lanjut mengenai, pertama, tantangan pendidikan di era disrupsi teknologi; kedua, solusi mengatasi tantangan pendidikan di era disrupsi teknologi; ketiga, memahami pandangan Alkitab tentang cara mengajar; dan kesimpulan atas setiap kajian yang dipaparkan. Berikut kajian yang dipaparkan.

\section{Tantangan Pendidikan di Era Disrupsi Teknologi}

Perkembangan teknologi atau yang disebut dengan disrupsi teknologi ini terjadi pada abad 21 yang di dorong dengan suatu perubahan yang drastis dari masyarakat industri menjadi industri teknologi dan informasi. Seorang ahli ekonomi, Suwardana menjelaskan disrupsi adalah suatu istilah yang mengambarkan keadaan yang terjadi akibat perubahan keadaan industri yang berawal dari perkembangan teknologi informasi yang telah berubah secara cepat. ${ }^{3}$ Artinya, perubahan yang terjadi akibat perkembangan teknologi merupakan hal yang sangat cepat terjadi, sehingga penulis berpendapat dengannya perubahan yang cepat terjadi ini membuat pendidikan atau proses pembelajaran mengalami kesulitan untuk menyesuaikannya dengan setiap perkembangan yang terjadi.

Lalu, apakah yang menjadi tantangan pendidik di Era Disrupsi teknologi? Berdasarkan pembahasan diatas, penulis merumuskan 2 tantangan yang dihadapi oleh pendidikan akibat cepatnya perkembangan teknologi berdasarkan kemendikbud, Totok Suprayitno. Berikut akan dipaparkan penulis.

1. Kurikulum

Menurut Totok, kurikulum merupakan pegangan sebagai bekal kegiatan belajar anak-anak di sekolah. ${ }^{4}$ Oleh sebab itu kurikulum sangat diperlukan dalam proses pembelajaran. Namun, kurikulum juga merupakan tantangan bagi pendidikan. Khususnya pendidikan Indonesia kurikulum yang diberikan merupakan pengarahan dari pemerintah dan dengan peraturan yang semakin ketat. Dan Indonesia mengganti kurikulum pendidikan setiap 10 tahun sekali, sedangkan perubahan terjadi hampir setiap kali.

Dengan demikian, muncul pertanyaan, apakah kurikulum harus berubah mengikut setiap perubahan yang terjadi? Pertanyaan inilah yang kerap kali menjadi pertanyaan bagi para pengajar. Menurut Sidjabat, menjadi guru atau pengajar tidak hanya memahami materi pembelajaran yang akan disampaikan. ${ }^{5}$ Sejalan dengan pendapat Sidjabat, bahwa menjadi guru tidak hanya memahami materi saja, melainkan

\footnotetext{
${ }^{3}$ Suwardana, H. (2018). Revolusi Industri 4. 0 Berbasis Revolusi Mental. JATI UNIK: Jurnal IImiah Teknik dan Manajemen Industri.

${ }^{4}$ Kompas.com, https://edukasi.kompas.com/read/2019/09/03/15390441/3-tantangan-pendidikan-eradisrupsi-teknologi-apa-saja?page=all. (Di akses 19 September 2019)

${ }^{5}$ B.S. Sidjabat. Mengajar Secara Profesional. (Bandung: Kalam Hidup), 66
} 
harus mencari tahu tentang bagaimana cara mengembangkan dan membuat efektif pembelajaran yang ia berikan kapada para murid. Dan harus memahami kurikulum yang akan diberikan kepada anak-anak didiknya.

2. Pembelajaran

Tantang kedua yang dihadapi pendidikan menurut Totok, adalah mengenai proses pembelajaran dan cara penyampaian materi yang akan diberikan kepada murid. ${ }^{6}$ Di era disrupsi teknologi sangatlah memudahkan seseorang dalam mendapatkan informasi yang diinginkan. Sehingga, para murid akan mudah mendapatkan informasi pembelajaran dengan melalui media online yang mudah diakses pada zaman perkembangan teknologi. Oleh sebab itu guru harus merubah cara menyampaikan materi dengan cara berbeda jika hanya menyampaikan dengan cara membaca buku maka tidak ada bedanya internet.

Dengan kemudahan dalam mengakses setiap informasi dengan mudah maka, setiap murid akan cenderung memiliki ketertarikan menyendiri karena sudah terlalu asik dengan media online yang diaksesnya melalui Handphone $(\mathrm{Hp})$ dan telah memberikan cukup pengaruh negatif bagi akademik murid. Keadaan yang terjadi seperti ini akan mengurangi hubungan yang humanis antara guru dengan murid, karena telah digantikan teknologi. Sehingga, esensi dari pendidikan kehilangan tujuannya dalam pembentukan manusia seutuhnya. ${ }^{7}$ Dan perubahan yang diharapkan setelah melaksanakan pengajaran tidak akan terwujud.

Tantangan diataslah yang cukup mempengaruhi dalam dunia pendidikan. Masih banyak lagi tantangan yang dihadapi oleh setiap para pengajar dan guru. Namun, penulis aja memaparkan kedua tantangan yang telah dijelaskan. Jika kedua tantangan tersebut dapat dipahami dan diatasi oleh para pengajar, maka pendidikan dapat berkembang bersama perkembangan teknologi yang semakin cepat.

\section{Solusi Mengatasi Tantangan Pendidikan di Era Disrupsi Teknologi}

Ada berbagai solusi dan cara yang sudah dilakukan untuk mengatasi setiap tantang-tantangan pendidikan di era disrupsi teknologi. Namun,yang terpenting perlu dilakukannya adalah evaluasi pendidikan yang dimana setiap para pengajar harus mengetahui hal-hal apa saja yang harus diubah dan diperhatikan di dalam perkembangan teknologi. Khususnya kurikulum yang menjadi dasar dan pegangan bagi murid haruslah diperhatikan serta metode pembelajaran yang telah dijelaskan diatas. Evaluasi pendidikan memiliki peran yang sangat penting untuk kemajuan pendidikan di era disrupsi teknologi, sehingga perlu dilakukanoleh setiap lembaga pendidikan khususnya di Indonesia.

Dunia pendidikan mengalami perubahan yang dikuasai oleh perkembangan teknologi, sehingga diharuskannya merancang kurikulum dan metode pembelajaran yang berbeda dan bahkan berbeda dari yang sekarang diterapkan. Perkembangan dalam metode pembelajaran yang telah menggeser peran guru sebagai sumber

\footnotetext{
${ }^{6}$ Kompas.com, https://edukasi.kompas.com/read/2019/09/03/15390441/3-tantangan-pendidikan-eradisrupsi-teknologi-apa-saja?page=all. (Di akses 19 September 2019)

${ }^{7}$ Fauzi, H., Islam, U., Sunan, N., \& Yogyakarta, K. (2017). Kurikulum 2013 Untuk Total Quality Education Di Indonesia. Jurnal Tarbawi, 14
} 
pengetahuan bagi para murid kini telah digantikan dengan murid sebagai peran utama harus dikembangkan dan ikuti perkembangannya. ${ }^{8}$ Penulis berpendapat, bahwa dunia pendidikan harus mengalami suatu perubahan juga dengan melalui peran murid yang menjadi peran utama dalam proses belajar mengajar. Sehingga, guru dapat memberikan suatu fenomena yang terjadi dan murid melakukan penelitian terhadap fenomena tersebut. Sehingga, penelitian tersebut dapat dilakukan dengan mencari informasi di media online, dengan kata lain perkembangan teknologi dapat dimanafaatkan untuk kemajuan pendidikan. Namun, berdasarkan penelitian trend international mathematic and science studies (TIMSS) kompetensi pelajar Indonesia sangat memprihatinkan. ${ }^{9}$ Menurut Istiyono dkk, kemampuan high order thinking skill (HOTS) rata-rata pelajar Indonesia masih dalam kategori rendah. ${ }^{10}$ Oleh sebab itu, para pelajar Indonesia perlu menjadi peran utama dalam proses pembelajaran, agar dapat meningkatkan kompetensi atau kemampuan pelajar Indonesia.

Peran pengajar merupakan kunci keberhasilan untuk membangun sikap dan nilai-nilai. Menjadi seorang pengajar harus menunjukkan antusiasmenya terhadap perkembang ilmu pengetahuan dan teknologi, dan memiliki keinginan untuk berupaya menggali dan mengkritisinya bersama muridnya dan hal ini akan cenderung ditiru para muridnya. ${ }^{11}$ Seorang pengajar harus mampu membangun komunikasi dengan para muridnya, sehingga keberhasilan dalam membangun sikap dan nilai-nilai dapat berjalan dengan baik.

Di dalam perkembangan teknologi diperlukannya para pelajar yang berpikir kritis, oleh sebab itu seorang pengajar harus mengembangkan muridnya untuk berpikir kritis. Sehingga, para pelajar mampu merespon derasnya informasi yang mudah didapatkan di era teknologi dan diharapkan para pelajar mampu memilah dan mengkritisi dengan akurat informasi yang diterimanya. ${ }^{12}$ Berdasarkan pernyataan diatas penulis berpendapat, bahwa perkembangan teknologi atau era disrupsi teknologi dalam pendidikan dapat diatasi dengan mengembangkan pikiran kritis agar setiap informasi yang terima oleh para pelajar dapat dikritisi dan dipilahnya.

\section{Pandangan Alkitab Tentang Cara Mengajar}

Setelah memahami setiap tantangan pendidikan di era disrupsi teknologi dan solusinya terhadap tantangan tersebut diharapkan setiap pengajar dapat memahaminya. Tidak hanya bagi pengajar sekuler, bagi para pengajar Kristen pun juga harus memperhatikan tantangan yang terjadi di era disrupsi teknologi. Oleh sebab itu, menjadi seorang pengajar Kristen haruslah berpegang kepada otoritas Alkitab maka,ia akan mengalami perubahan hidup yang membawanya tetap bersemangat dalam

\footnotetext{
${ }^{8}$ Daniel Dhakidae. ERA DISRUPSI Peluang dan Tantangan Pendidikan Tinggi Indonesia. (Jakarta:AIPI), 262-263

${ }^{9}$ Ulya, H. (2016). Profil kemampuan pemecahan masalah siswa bermotivasi belajar tinggi berdasarkan ideal problem solving. Jurnal Konseling Gusjigang, 2(1).

${ }^{10}$ Istiyono, E., Mardapi, D., \& Suparno, S. (2014). Pengembangan tes kemampuan berpikir tingkat tinggi fisika (pysthots) peserta didik SMA. Jurnal Penelitian dan Evaluasi Pendidikan,

${ }^{11}$ Juliana Murniati. Era Disrupsi: Tantangan dan Peluang bagi PT anggota APTIK. (Paper dipresentasikan dalam Hari Studi APTIK 2017), 6

${ }^{12}$ Ibid. 7
} 
menjalankan tugas mengajar. Hal ini dapat terjadi kepada orang-orang yang mau membuka hati dan tekun mempelajarin, merenungkan, serta menghayati ajaran Alkitab. ${ }^{13}$ Jika demikian, lantas apa yang dikatakan Alkitab tentang mengajar.

Sidjabat mengatakan di dalam bukunya bahwa " Informasi dalam Alkitab itu sangat menarik kerena memberi nilai pengajaran yang luar biasa, apalagi bagi para guru. Misalnya,guru yang baik harus memiliki kesabaran dalam mendidik serta mengarahkan peserta didiknya. Guru yang baik juga harus dapat mengomunikasikan isi hati dan pemikirannya kepada peserta didik, bahkan menolong mereka ketika berada dalam kesulitan."14 setuju dengan pendapat tersebut bahwa Alkitab memberikan nilai-nilai pengajaran yang luar bisa bagi para guru untuk menjadi yang baik bagi para muridnya, sehingga guru harus memiliki kesabaran dalam mendidik dan mengarahkan setiap anak didiknya. Dalam proses pembelajaranpun guru tidaklah hanya menyampaikan materi kepada anak didiknya, melainkan hendaklah membantu ketika anak didiknya mengalami kesulitan.

Sama seperti halnya dengan para pengajar sekuler, pengajar Kristen pun juga mengalami tantangan yang sama di era disrupsi teknologi yang terjadi. Namun, perbedaan antara guru Kristen dan sekuler sangatlah jauh. Guru Kristen dalam melaksanakan tugas mengajarnya selalu disertai Roh Kudus untuk menghadapi setiap tekanan dan tantangan yang dihadapinya. Seperti yang tertulis dalam Kisah Para Rasul $^{15}$ yang dimana Roh Kudus memimpi, mengendalikan,dan member kuasa atas murid-murid didalam pekerjaan mereka. Meskipun, disisi lain banyak tekanan dari tokoh-tokoh agama Yahudi, namun para rasul tetap mengajar didalam nama Yesus. ${ }^{16}$

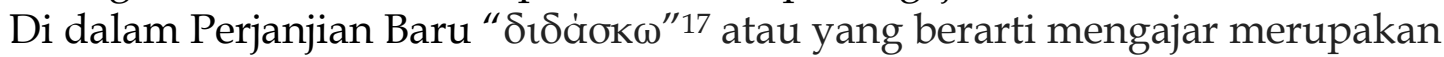
istilah yang disering dipakai dalam penulisan yang menyatakan suatu kegiatan mengajar yang berpusat kepada Yesus. Istilah ini juga mengandung arti menyalurkan seperangkat doktrin yang harus dikuasai agar dapat lestari. ${ }^{18}$ Dengan kata lain mengajar menurut Perjanjian Baru adalah suatu kegiatan yang menyalurkan sesuatu pengetahuan (doktrin) yang harus dilestarikan. Oleh sebab itu, mengajar harus tetap dilakukan meskipun banyak tantang yang dihadapi, agar setiap pengetahuan atau ilmu yang disampaikan kepada murid dapat terjaga kelestariannya.

Seorang guru Kristen dapat melakukan cara mengajarnya dengan apa yang sesuai dengan teladan Yesus sebagai Guru Agung. Bahwa Ia mengajar melalui perbuatan dan perkataan serta tanda-tanda dan kuasa. Seperti yang dikemukankan oleh Injil Matius bahwa Yesus mengajar berdasarkan otoritas, wibawa, dan kuasa. ${ }^{19}$ Para pengajar Kristen dapat mempelajari teladan Yesus untuk memahami peran Yesus sebagai Guru Agung agar dapat mengerti tujuan, metode, dan bahan pengajaran.

\footnotetext{
${ }^{13}$ B.S. Sidjabat. Mengajar Secara Profesional. (Bandung: Kalam Hidup), 34

${ }^{14}$ Ibid. 39

${ }^{15}$ Lihat dalam Kis. $2: 42 ; 4: 2,18 ; 5: 2,28,42 ; 11: 26$

${ }^{16} \mathrm{Ibid} .53$

${ }^{17}$ Bahasa Yunani dari mengajar

${ }^{18}$ B.S.Sidjabat. Mengajar Secara Profesional. (Bandung: Kalam Hidup). 26

${ }^{19}$ Ibid.45
} 


\section{Kesimpulan}

Tantang pendidikan di era disrupsi teknologi atau perkembangan ilmu teknologi dan informasi dapat disimpulkan bahwa seharusnya dengan adanya perkembangan tersebut memudahkan untuk berkembangannya dunia pendidikan. Namun, yang terjadi justru sebaliknya, seperti yang telah dipaparkan diatas bahwa banyak tantangan yang harus dihadapi para pengajar dalam melaksanakan tugasnya sebagai pengajar di era disrupsi teknologi. Akan tetapi, keadaan akan berbeda jika para pengajar mampu memahami tantangan dan cara mengatasinya, maka dunia pendidikan akan mengalami perkembangan yang maju bersama-sama dengan perkembangan teknologi.

Begitu juga bagi para guru Kristen yang harus tetap berpegang kepada otoritas Alkitab yang menuntutnya untuk mengalami perubahan dalam kehidupannya dan membuat semangat dalam melaksanakan pekerjaan mengajarnya. Dengan tetap mengandalkan Roh kudus di dalam pekerjaan mengajarnya maka Roh Kudus secara tidak langsung akan menolong para pengajar dalam melakukan pekerjaannya meskipun menghadapi berbagai tantangan.

Alkitab

\section{Daftar Pustaka}

Daniel Dhakidae. 2017. ERA DISRUPSI Peluang dan Tantangan Pendidikan Tinggi Indonesia. Jakarta:AIPI

Fauzi, H., Islam, U., Sunan, N., \& Yogyakarta, K. 2017. Kurikulum 2013 Untuk Total Quality Education Di Indonesia. Jurnal Tarbawi,

Istiyono, E., Mardapi, D., \& Suparno, S. 2014. Pengembangan tes kemampuan berpikir tingkat tinggi fisika (pysthots) peserta didik SMA. Jurnal Penelitian dan Evaluasi Pendidikan,

Murniati, Juliana. Era Disrupsi: Tantangan dan Peluang bagi PT anggota APTIK. (Paper dipresentasikan dalam Hari Studi APTIK 2017)

Sidjabat, B.S.2009. Mengajar Secara Profesional. Bandung: Kalam Hidup

Surya, Moh. 2004. Psikologi Pembelajaran dan pengajaran. Bandung: Pustaka Bani Quraisy

Suwardana, H. 2018. Revolusi Industri 4. 0 Berbasis Revolusi Mental. JATI UNIK: Jurnal Ilmiah Teknik dan Manajemen Industri

Ulya, H. 2016. Profil kemampuan pemecahan masalah siswa bermotivasi belajar tinggi berdasarkan ideal problem solving. Jurnal Konseling Gusjigang, 2(1).

\section{Sumber Internet:}

Kompas.com, https://edukasi.kompas.com/read/2019/09/03/15390441/3tantangan-pendidikan-era-disrupsi-teknologi-apa-saja?page=all. (Di akses 19 September 2019) 